\title{
The evolution of natural killer cell receptors
}

\author{
Paola Carrillo-Bustamante ${ }^{1,2}$ • Can Keşmir ${ }^{1}$ - Rob J. de Boer ${ }^{1}$
}

Received: 16 July 2015 / Accepted: 11 August 2015 / Published online: 21 September 2015

(C) The Author(s) 2015. This article is published with open access at Springerlink.com

\begin{abstract}
Natural killer (NK) cells are immune cells that play a crucial role against viral infections and tumors. To be tolerant against healthy tissue and simultaneously attack infected cells, the activity of NK cells is tightly regulated by a sophisticated array of germline-encoded activating and inhibiting receptors. The best characterized mechanism of NK cell activation is "missing self" detection, i.e., the recognition of virally infected or transformed cells that reduce their MHC expression to evade cytotoxic T cells. To monitor the expression of MHC-I on target cells, NK cells have monomorphic inhibitory receptors which interact with conserved MHC molecules. However, there are other NK cell receptors (NKRs) encoded by gene families showing a remarkable genetic diversity. Thus, NKR haplotypes contain several genes encoding for receptors with activating and inhibiting signaling, and that vary in gene content and allelic polymorphism. But if missing-self detection can be achieved by a monomorphic NKR system why have these polygenic and polymorphic receptors evolved? Here, we review the expansion of NKR receptor families in different mammal species, and we discuss several hypotheses that
\end{abstract}

Paola Carrillo-Bustamante

paola.carrillo-bustamante@bioquant.uni-heidelberg.de

1 Theoretical Biology \& Bioinformatics, Department of Biology, Utrecht University, Utrecht, The Netherlands

2 Center for Modeling and Simulation in the Biosciences, Bio-Quant Center, Heidelberg University, Heidelberg, Germany possibly underlie the diversification of the NK cell receptor complex, including the evolution of viral decoys, peptide sensitivity, and selective MHC-downregulation.

Keywords NK cell receptors $\cdot$ Host-pathogen co-evolution · Agent-based modeling · KIR · Viral evasion

\section{Introduction}

Natural killer (NK) cells are large granular cells that play a pivotal role in controlling viral infections and tumors (Vivier et al. 2008). To be tolerant to healthy tissue, and yet attack infected cells, the activity of NK cells must be tightly regulated. Unlike B and T cells, NK cells do not undergo gene rearrangements to generate the repertoire of cell surface receptors. Instead, they use germline-encoded inhibiting and activating receptors.

Inhibiting NK cell receptors is characterized by the presence of immunoreceptor tyrosine-based inhibitory motifs (ITIM) in their cytoplasmic tail that can decrease the state of activation (Vivier et al. 2004). Activating receptors lack ITIMs, but contain a positively charged amino acid (arginine or lysine) in their transmembrane region, and are associated with signaling adaptor molecules containing immunoreceptor tyrosine-based activating motifs (ITAM), such as DAP10, DAP12, or Fc $\gamma$ R (Lanier 2005). NK cells integrate signals derived from both types of receptors upon cellular contact, thereby determining whether or not they should initiate effector functions.

Many inhibiting NK cell receptors interact with major histocompatibility complex (MHC) class I proteins, which are ubiquitously expressed on the surface of nucleated cells. 
Because of the abundant expression of MHC-I on many cells, NK cells remain non-responsive to healthy tissue. But when cells have a decreased expression of MHC-I, which can occur during certain viral infections or in tumors, they can become target for NK cell killing. The process by which NK cells detect cells with aberrant MHC-I expression has been coined by Kärre et al. as "missing-self" detection (Ljunggren and Kärre 1990).

For the development of functional NK cells in the bone marrow, interactions between inhibiting receptors and MHC-I are necessary (Raulet et al. 1997; Raulet and Vance 2006; Höglund and Brodin 2010). This process is called NK cell education and determines the threshold for activation in mature NK cells. Depending on the strength of the inhibitory signals received during development, every NK cell balances its activation threshold as a rheostat to adapt to the particular MHC phenotype of their host (Brodin et al. 2009). The expression of both activating and inhibiting receptors during development is thought to occur in a sequential and stochastic manner (Raulet et al. 1997; Moretta et al. 1990; Valiante et al. 1997; Husain et al. 2002), giving rise to a large NK cell repertoire composed of 300035,000 functionally different NK cell subsets (Horowitz et al. 2013).

\section{Evolution of NK cell receptors}

Genes encoding NK cell receptors are clustered in two main gene complexes: the natural killer complex (NKC) encoding C-type lectin-like molecules, and the leukocyte receptor complex (LRC), encoding the immunoglobulin-like receptors (Trowsdale 2001). Although these gene clusters are present in several species, there is extensive evidence for species-specific expansion of different NK cell receptor genes (Averdam et al. 2009; Futas and Horin 2013; Gagnier et al. 2003; Guethlein et al. 2007a, b; Iizuka et al. 2003; Kelley et al. 2005; McQueen et al. 1998; Takahashi et al. 2004; Trowsdale 2001; Wilhelm et al. 2002, and see Fig. 1), resulting in a fascinating complexity of interactions between MHC-I and NK cell receptors. The NK cell receptor expansions known so far are described in detailed below.

\section{Expansion of NK cell receptors in primates}

In humans, the main NK cell receptors for MHC-I are the killer immunoglobulin-like receptors (KIRs), which are located in the LRC on chromosome 19q13.4 (Wende et al. 1999). The haplotypes encoding KIRs exhibit great differences in gene content and allelic polymorphism, with up to 17 genes encoded over approximately 150 kilo bases (Parham 2005; Martin et al. 2000; Wende et al. 1999;
Barten et al. 2001; Wilson et al. 2000; Trowsdale 2001). The marked differences in gene content are thought to be the result of non-reciprocal crossovers in the tandemly arranged genes, causing hybrid loci or contraction and expansion of the haplotype (Vilches and Parham 2002; Martin et al. 2003; Martin et al. 2000; Wilson et al. 2000; Wende et al. 1999).

KIRs can have either two (KIR2D) or three (KIR3D) extracellular immunoglobulin-like domains and contain either long cytoplasmic tails with ITIM motifs or short cytoplasmic tails comprising ITAMS (Vilches and Parham 2002). An exception is KIR2DL4 which has a cytoplasmic long tail and possesses a positively charged residue in the transmembrane region, allowing association with the activating protein $\mathrm{Fc} \gamma \mathrm{R}$ (Kikuchi-Maki et al. 2005).

KIRs started expanding between 31 and 40 million years ago (Martin et al. 2000), resulting in a rapid and speciesspecific diversification in primates (Martin et al. 2000). Old world monkeys, apes, and humans have a common organization of the KIR gene complex, sharing four phylogenetic lineages (I,II,III, and V), which are characterized by their structure and specificity for MHC-I (Parham and Moffett, 2002; Vilches and Parham 2013 and see Table 1). In humans, the lineage I KIR binds HLA-G-peptide complexes (Rajagopalan 2010), lineage II KIRs recognize epitopes A3/A11 on HLA-A, and Bw4 on HLA-A and B, and lineage III KIRs bind to HLA-C epitopes $\mathrm{C} 1$ and $\mathrm{C} 2$ (Trowsdale et al. 2001). These epitopes are mutually exclusive and differ in unique residues that are involved in the KIR-pMHC interaction (Trowsdale et al. 2001). The dimorphism among HLA-C molecules at position 80, i.e., either asparagine or lysine, determines the classification of HLA-C1 and HLAC2 alleles (Colonna et al. 1993; Fan et al. 2001). The Bw4 epitope, on the other hand, is defined by residues 77 83 (Sanjanwala et al. 2008; Gumperz et al. 1997; Gumperz et al. 1995). As shown by a vast range of structural and functional studies (Colonna et al. 1993; Vivian et al. 2011; Schafer et al. 2014; Saunders et al. 2015), single amino acid substitutions in these key residues can have large effects on KIR binding. Ligands for KIR lineage V have to still be identified.

In the LRC, there are some differences in gene content and specificity of the KIRs across primate species. Importantly, the marked differences go hand in hand with the evolution of MHC-I genes. In macaques, carrying duplicated MHC-A and MHC-B genes (Daza-Vamenta et al. 2004; Shiina et al. 2006), the Bw4 motif is important for binding of a large collection of several lineage II KIRs (Adams and Parham 2001; Bimber et al. 2008; Blokhuis et al. 2010, 2011; Kruse et al. 2010; Schafer et al. 2014). Consistent with the observation that macaques lack MHC-C molecules, they have only one lineage III KIR, with members that do not seem to bind any MHC-class I (Bimber et al. 2008; Hershberger et al. 2001). Orangutans, on the 


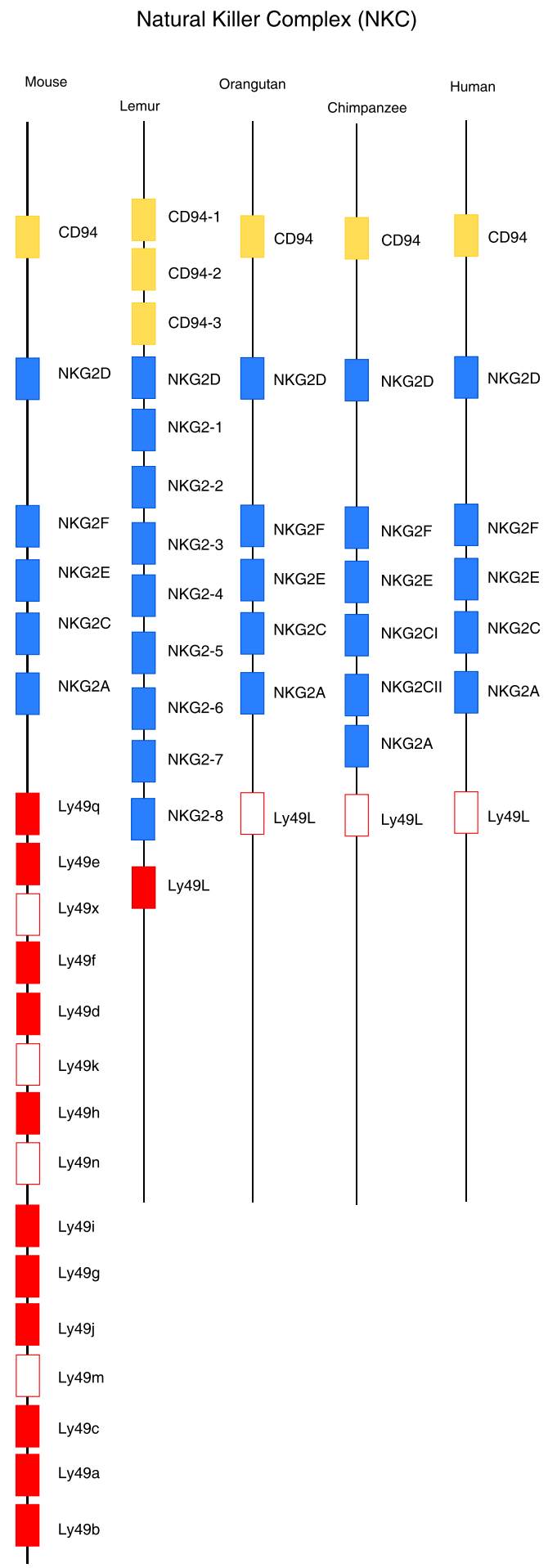

Fig. 1 Cartoon of the NK cell receptor complexes. The NK cell receptor complexes. This figure shows a schematic organization of some of the genes encoded in the NKC (left) and in the KIR region of the LRC (right) for different species. The NKC encodes genes from the CD94 (yellow boxes), NKG2 (blue), and Ly49 (red) families. While higher primates have one copy of a non-functional Ly49 gene (white boxes), lemurs have one functional Ly49, and mice encode 15 Ly49 genes, 11 of which are functional. Lemurs have expanded their CD94/NKG2

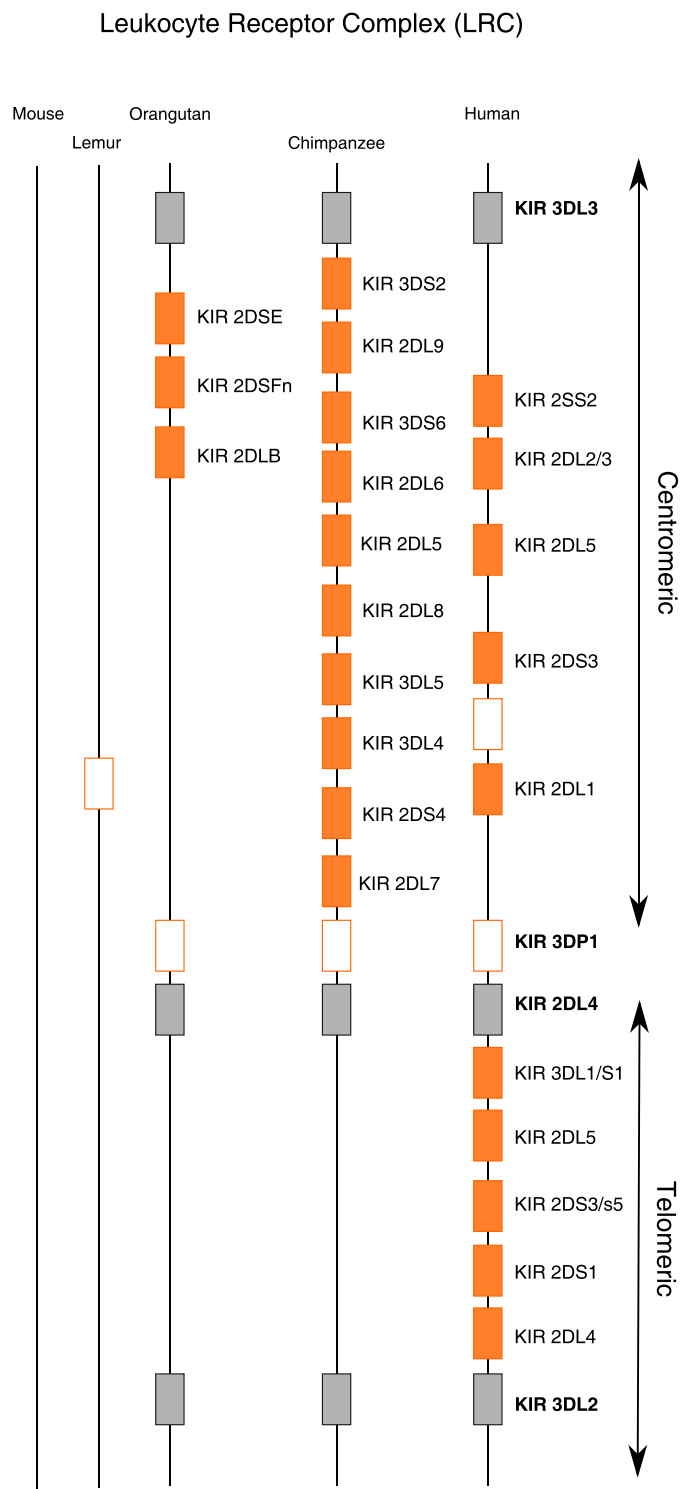

system, with three CD94 genes, and eight NKG2 genes. KIRs (orange boxes) are encoded in the LRC. All higher primates share a common organization within this gene complex. Between the four framework genes, i.e. KIR3DL3, KIR2DL4, KIR3DL2, (gray boxes), and the pseudo gene KIR3DP1 (white boxes), the gene content varies across species. Lemurs have only one non-functional copy, and mice do not encode any KIR in the LRC. The gene order was taken from the literature sources mentioned in the text and from Kelley et al. (2005) 
Table 1 Ligands of activating and inhibiting human KIRs

\begin{tabular}{lll}
\hline & Lineage & Ligand \\
\hline Activating KIR & & \\
2DS1 & III & HLA-C2 \\
2DS2 & III & HLA-C1, HLA-A*11:01 \\
2DS3 & III & unknown \\
2DS4 & III & HLA-C*05:01, A*11:02, C*16:01 \\
2DS5 & III & unknown \\
3DS1 & II & unknown \\
& & \\
Inhibiting KIR & & \\
2DL1 & III & HLA-C2 \\
2DL2 / 2DL3 & III & HLA-C1, HLA-C2, HLA-B*46:01, and \\
& & HLA-B*73:01 (C1 epitope) \\
2DL4 & I & HLA-G (might be an intracellular \\
& & interaction) \\
2DL5 & I & unknown \\
3DL1 & II & HLA-A with Bw4 motif, HLA-Bw4 \\
3DL2 & II & HLA-A3/A11 \\
3DL3 & V & unknown \\
\hline
\end{tabular}

other hand, carry fewer MHC-A and MHC-B loci than macaques, and encode only one lineage II KIR accordingly. Orangutans were the first primates to evolve MHC-C (C1 epitope), corresponding to the expansion of their lineage III KIRs (Guethlein et al. 2007b). Lineage III KIRs expanded further in chimpanzees, correlating with the evolution of the C2 epitope in MHC-C. Chimpanzees have both inhibiting and activating KIRs, and eight of them recognize MHC-C only (Abi-Rached et al. 2010).

Humans, in contrast, have only seven lineage III KIRs and two lineage II KIRs, with three KIR genes showing specificity for HLA-C, including the inhibiting KIR2DL2/3, and KIR2DL1, and the activating KIR2DS2 (see Table 1). Additionally, humans are the only species that have undergone specific expansion in the telomeric part of the KIR complex (Abi-Rached et al. 2010). While the centromeric part of human KIR haplotypes is more similar to chimpanzee KIR haplotypes (Abi-Rached et al. 2010), the telomeric region in humans accumulated genes that show mainly activating potential, and that have little or no binding affinity to HLA-I molecules, such as KIR2DS2, 2DS3, and 2DS5 (Moesta et al. 2010; Pyo et al. 2010). This clear distinction between centromeric and telomeric genes allowed for the distinction of the two haplotype groups, A and B. Both haplotypes are present in all human populations (Hollenbach et al. 2010) (including Japanese Yawata et al. 2006; Amerindian Gendzekhadze et al. 2009; African Norman et al. 2013; Polynesian Nemat-Gorgani et al. 2014), differ in frequency and are maintained by balancing selection (Yawata et al. 2006), indicating their essential role for long-term survival (Gendzekhadze et al. 2009).

The other receptor cluster in primates is the NKC. The main members of these gene families are the Ly49 and the NKG2 genes. Primates have only one gene of the Ly49 family, which is a pseudo gene, but their NKC encodes several NKG2 genes (Renedo et al. 1997; Khakoo et al. 2000; LaBonte et al. 2001; Guethlein et al. 2002). Members of the NKG2 family include the inhibiting NKG2A, the activating $\mathrm{NKG} 2 \mathrm{C}, \mathrm{NKG} 2 \mathrm{E}$, and $\mathrm{NKG} 2 \mathrm{D}$, and the NKG2F, for which no function has been yet determined (Lazetic et al. 1996). NKG2 proteins dimerize with the invariant CD94 molecule on the cell surface, which contains a short cytoplasmic domain and transduces the activating or inhibiting signal (Lazetic et al. 1996). An exception is NKG2D, an activating receptor, which shares little sequence similarity with the other members, and associates with the activating molecule DAP10 on the cell surface.

The ligands of NKG2A and NKG2C include the conserved and non-classical HLA-E molecule in humans and Qa- ${ }^{b}$ in mice (Borrego et al. 1998; Braud et al. 1998; Petrie et al. 2008; Zeng et al. 2012), which present peptides derived from the leader sequences of the classical HLA-A, HLA-B, and HLA-C molecules in humans, and from $\mathrm{H} 2$ molecules in mice. The engagement of NKG2A by HLA-E or Qa- $1^{b}$ inhibits the activity of NK cells, preventing target cell lysis. In higher primates, both NKG2A and MHC-E (i.e., receptor and ligand) are very well conserved (Shum et al. 2002), presenting a system for detection of "gross" MHC-I expression, that unlike KIRs is highly conserved.

Lemurs, on the other hand, exhibit only one single nonfunctional KIR gene in their LRC, but they have diversified the genes encoding CD94 and NKG2 (Averdam et al. 2009). Located in lemur chromosome 7 , the NKC comprises three CD94 genes and five to eight inhibiting and activating genes. Like KIRs in higher primates, the CD94 and NKG2 genes in lemurs are highly polymorphic, with many of the polymorphic positions representing functionally relevant sites, i.e., residues involved in binding of MHC class I ligands and their presented peptides (Averdam et al. 2009). The homologs of HLA-E have not been yet identified in prosimians, but the ligands for the NKG2 receptors are expected to be the lemur MHC-I molecules (Averdam et al. 2009).

Importantly, Averdam et al. showed that all possible CD94/NKG2 combinations are able to form heterodimers at the cell surface, giving rise to a great combinatorial diversity. For instance, the combination of three CD94 and five NKG2 molecules in the gray mouse lemur or three CD94 and eight NKG2 molecules in the ruffed lemur gives rise to 15 or 24 different NK cell receptors, respectively, 
(Walter 2011; Averdam et al. 2009). An exchange of the CD94 or the NKG2 subunit can influence the binding specificity for MHC class I ligands, changing the functionality of the NK cell receptors (Averdam et al. 2009). Thus, lower primates seem to have evolved an alternative system for variable NK cell receptors.

\section{Expansion of NK cell receptors in rodents}

The LRC is located on chromosome 7 in mice and on chromosome 4 in rats (Kirkham and Carlyle 2014; Iizuka et al. 2003; Schenkel et al. 2013). The murine LRC does not contain any of the KIRs that bind MHC-I in humans (Martin et al. 2002a), but contains orthologs of human GP6 (Trowsdale et al. 2001), NCR1, RPS9, and LAIR1 (Martin et al. 2003), and genes of the Pir family, which share sequence identity with the human LILRs (Kubagawa et al. 1999).

Instead of having polygenic and polymorphic KIRs, rodents have expanded their Ly49 genes, resulting in a remarkable diversity across different inbred mouse strains (Kirkham and Carlyle 2014; lizuka et al. 2003). While the mouse Ly 49 complex comprises at least 20 genes and pseudo genes (Wilhelm et al. 2002), the variation is even larger in rats, with 19 functional genes and 15 pseudo genes (Nylenna et al. 2005; Flornes et al. 2010). Table 2 shows the most important known receptors in mouse strains studied so far (Rahim et al. 2014). Ly49 receptors in mice are functionally similar to KIRs in humans, having both inhibiting and activating receptors, and genes encoding proteins that preferentially bind mouse MHC-I (Schenkel et al. 2013). Although several ligands for activating Ly49 receptors remain unknown, some activating receptors bind viral encoded proteins (see below).

\section{NK cell receptors in other species}

At least five highly conserved polymorphic Ly49 genes have been found in some equids, including horses, asses and zebras (Takahashi et al. 2004; Futas and Horin 2013). By contrast, only one single Ly49 has been found in cattle (McQueen et al. 1998), domesticated dogs and cats, and pigs (Gagnier et al. 2003). Cattle have also functional KIRs (Parham and Moffett 2013; Guethlein et al. 2007a; Allan et al. 2015). Opposite to primate KIRs, which diverged from the founder gene KIR3DL, cattle expanded their founder gene KIR3DLX. In every species, the gene that was not diversified became nonfunctional (Guethlein et al. 2007a; Dobromylskyj and Ellis 2007). No species studied so far is known to have two expanded NK cell receptor families (Parham and Moffett 2013), but several species diversify neither, keeping both KIR and Ly49 as one single copy genes (Hammond et al. 2009).
Table 2 Ly49 haplotypes in four known mouse strains with their response to MCMV (modified from Rahim et al. 2014)

\begin{tabular}{|c|c|c|c|}
\hline \multicolumn{4}{|l|}{ Mouse strain } \\
\hline NOD & 129 & B6 & BALB \\
\hline \multicolumn{4}{|c|}{ Response to MCMV } \\
\hline Susceptible & Susceptible & Resistant & Susceptible \\
\hline \multicolumn{4}{|l|}{ Activating } \\
\hline Ly49D & Ly49P & Ly49D & Ly49L \\
\hline Ly49H & Ly49R & Ly49H & \\
\hline Ly49M & Ly4UP & & \\
\hline \multicolumn{4}{|l|}{${\text { Ly } 49 P_{1}}_{1}$} \\
\hline \multicolumn{4}{|l|}{$\mathrm{Ly}_{49 \mathrm{P}_{3}}$} \\
\hline \multicolumn{4}{|l|}{ Ly49U } \\
\hline \multicolumn{4}{|l|}{ Ly49W } \\
\hline \multicolumn{4}{|l|}{ Inhibiting } \\
\hline Ly49A & Ly $49 B^{b}$ & Ly49A & Ly49A \\
\hline Ly49B ${ }^{b}$ & Ly49E & Ly49B $^{b}$ & Ly49B ${ }^{b}$ \\
\hline Ly49C & $\mathrm{Ly}_{49 \mathrm{EC}_{2}}$ & Ly49C & Ly49C \\
\hline Ly49E & Ly $49 \mathrm{G}^{b}$ & Ly49E & Ly49E \\
\hline Ly49F & $\mathrm{Ly}_{49 \mathrm{I}_{1}}{ }^{b}$ & Ly49F & Ly49G \\
\hline $\mathrm{Ly}_{4} 9 \mathrm{G}_{2}$ & Ly490 & Ly49G & Ly49I \\
\hline Ly49I & Ly49Q $_{1}$ & Ly49I & Ly49Q \\
\hline \multirow[t]{3}{*}{ Ly49Q } & Ly49S & Ly49J & \\
\hline & Ly49T & Ly49Q & \\
\hline & Ly49V & & \\
\hline
\end{tabular}

\section{Why are NK cell receptors polygenic and polymorphic?}

The evolution of variable NK cell receptor genes is expected to have been shaped by several factors determining fitness and survival, like pathogen resistance, detection of polymorphic ligands like MHC-I, and reproductive success (Parham and Moffett 2013). The inter- and intra-species gene diversity indicates their rapid evolution. Importantly, the independent convergent evolution of variable NK cell receptors in several different species highlights their functional importance. However, the exact evolutionary selection pressure whereby NK cell receptors became polymorphic and polygenic remains unresolved. The conserved inhibitory receptor NKG2A demonstrates that abnormalities in MHC-I expression, i.e., missing-self, can be detected without a polygenic and polymorphic NK cell receptor system. Why then have these polygenic and polymorphic receptors evolved? 


\section{Reproductive success}

Since the divergence from chimpanzees, hominids have evolved several changes in aspects of locomotion, anatomy, and reproduction. Two key aspects of this human specific evolution affect the reproductive success: bipedalism and larger brain size. The evolution of bipedalism imposed drastic anatomic changes in the size and shape of the human female pelvis, affecting directly the size of the birth canal. While the size of the birth canal was decreasing, the evolution of larger brains was imposing additional challenges for a successful birth (Parham and Moffett 2013).

The evolution of bigger brain sizes required more blood supply in the placenta (Leonard et al. 2007), a process that has been achieved by a remodeling of the uterine arteries (reviewed in Wallace et al. 2012). Arterial remodeling occurs thanks to extra-villous trophoblast (EVT) cells. EVT are fetal cells invading the uterus, transforming the spiral arteries into large vessels that are able to provide adequate blood supply to the growing fetus (Moffett-King 2002). Preeclampsia and recurrent miscarriage have been associated with a compromised arterial remodeling (Wallace et al. 2012).

A successful EVT invasion depends on the interactions of EVT with uterine NK cells. The activation of uterine $\mathrm{NK}$ cells is important for arterial remodeling, as it results in the release of cytokines, which in turn promote migration of the trophoblasts (Xiong et al. 2013). Because EVT uniquely express HLA-C (lacking HLA-A or HLA-B), and uterine NK cells preferentially express HLA-C-specific KIRs (Sharkey et al. 2008), several correlations between reproductive success and particular KIR/HLA-C combinations have been found (Hiby et al. 2004, 2010, 2014). The presence of HLA alleles in the fetus binding more inhibiting than activating receptors of the mother's NK cells results in compromised arterial remodeling and reduced fetal growth (Kieckbusch et al. 2014). Accordingly, mothers being homozygous for KIR A haplotypes have a high risk of developing preeclampsia if the fetus carries one $\mathrm{C} 2$ allele, as KIR A homozygous individuals have two copies of the inhibiting KIR2DL2, which binds strongly to C2 (Hiby et al. 2004, 2010, 2014).

The evolution of larger brain sizes started mainly in Homo erectus (Robson and Wood 2008) and correlates with the emergence of KIR B haplotypes that encode more activating KIRs than KIR A haplotypes. However, the evolution of more activating KIRs is not always beneficial for reproduction, as NK cell-mediated placentation can lead to large babies that are not able to pass through the birth canal, causing obstructed labor (Hiby et al. 2014). A successful placentation is hence dependent on a tight NK cell-mediated regulation. Thus, the pressure for a successful reproduction could drive and maintain inhibiting and activating receptors specific for MHC-I. However, because humans are the only species with a narrow birth canal requiring deep placentation (Moffett and Loke 2006), it is not likely that reproductive success would exert sufficient selection pressure to expand and maintain a set of polygenic and polymorphic NK cell receptors in other species.

\section{Response to viral infections}

Because of the evolutionary arms race between infectious agents and the host's immune system, another possible explanation for the diversification of NK cell receptors is the selection pressures imposed by various successful immuno-evasive mechanisms evolved by several pathogens (Lanier 2008; Sun and Lanier 2009). There is extensive evidence of associations between particular NKRs and the viral control caused by viruses, including cytomegalovirus (CMV), human immunodeficiency virus (HIV-1), and hepatitis $\mathrm{C}$ virus (HCV).

\section{Role of KIRs in human diseases}

Several human studies have provided evidence that some NKRs may be directly involved in viral control. Associations between particular KIR alleles and disease outcome have been found in HIV-1, HCV, and Influenza (Jamil and Khakoo 2011).

During HIV-1 infection, there is an expansion of $3 \mathrm{DS} 1^{+} \mathrm{NK}$ cells, and this expansion is dependent on the presence of the Bw4-80I epitope (Alter et al. 2009; Pelak et al. 2011). The expansion of selected NK cell subsets could be beneficial to the host due to an immediate and strong NK cell response. Indeed, individuals carrying these KIR-HLA combinations showed lower viremia and a slower progression to AIDS (Martin et al. 2002b). Furthermore, an increased number of KIR3DS1 (caused by a higher copy number variants of KIR3DL1/S1) was correlated with a lower set viral point in the presence of HLA-Bw4-80I (Pelak et al. 2011). All these studies show an important role of the KIR3DS1- Bw4-80I pair in the immune response to HIV infection. However, there is no evidence for direct binding between KIR3DS1 and HLA-Bw4 molecules (Gillespie et al. 2007; O'Connor et al. 2007; Carr et al. 2007), suggesting that the KIR3DS1 ligand interactions might be finely regulated, e.g., via the presented peptide (O'Connor et al. 2015).

NK cells expressing the inhibiting receptors 2DL2/L3 exhibit increased degranulation when they respond to $\mathrm{HCV}$ infected target cells (Amadei et al. 2010). Both 2DL3 and 2DL2 bind HLA-C1 epitopes, but they differ in their binding affinities, with 2DL2 binding stronger than 2DL3 (Winter et al. 1998). Because of the weaker inhibiting interaction, homozygous individuals for the 2DL3-HLA-C1 pair control 
$\mathrm{HCV}$ infection better and can even experience spontaneous clearance (Khakoo et al. 2004; Romero et al. 2008). Additionally, a protective effect of the activating 3DS1 in combination with HLA-Bw4-I80 in hepatocarcinoma has been found in patients with chronic HCV infection (LópezVázquez et al. 2005).

Studies of human influenza A virus (IAV) have also shed light on NK cell responsiveness depending on KIR-HLA genotypes. As shown by multicolor flow cytometry, NK cells from individuals homozygous for the 2DL3-C1 pair had a stronger activation (i.e., IFN- $\gamma$ secretion and degranulation) to IAV infected cells than those homozygous for 2DL1-C2 (Ahlenstiel et al. 2008). Another study of patients infected with 2009 pandemic IAV strain (H1N1/09) established that patients suffering from severe and pathological reactions against the virus lack functional receptor-ligand pairs (La et al. 2011). Patients carrying inhibiting 3DL1 but lacking HLA-Bw4 molecules, as well as patients positive for 2DL1 and lacking HLA-C2 alleles, were higher in ICU patients relative to healthy controls or patients with mild reactions against $H 1 N 1 / 09$. This study suggests that a lack of KIR-mediated inhibition might lead to NK cell dysfunction and with it to an immunopathological outcome.

These few examples mirror the large range of studies associating KIR-MHC combinations with the outcome of diseases. However, the lack of well-characterized ligands for several receptors and specific monoclonal antibodies for detecting specific KIRs limit the understanding of the precise molecular mechanisms underlying this associations and with it the precise functional role of these receptors upon infection.

\section{Selective downregulation of $M H C-I$}

Several viruses, including Epstein-Barr-Virus (EBV), CMV, and HIV decrease the expression of MHC-I on the cells they have infected to escape from the $\mathrm{T}$ cell immune responses. Interestingly, the downregulation does not always affect all MHC molecules in the same way, and some viruses, e.g., HIV and CMV, have evolved mechanisms that target only particular loci (reviewed in Nash et al. 2014). In humans, the HLA molecules presenting peptides to T cells ( $\mathrm{A}$ and $\mathrm{B}$ loci) tend to be downregulated, while those HLA molecules inhibiting NK cells ( $\mathrm{C}$ and $\mathrm{E}$ loci) remain unchanged, suggesting that selective $\mathrm{MHC}$ downregulation could be a viral strategy to avoid missing-self detection (Table 3).

HCMV encodes several immunoevasin proteins that selectively downregulate the expression of MHC-I on the cell surface (Nash et al. 2014), such as US2 and US11, targeting specific and non overlapping HLA-A and HLA-B molecules, by promoting their export into the cytosol for proteosomal degradation (Llano et al. 2003; Gewurz et al. 2001; Schust et al. 1998). In addition to selective MHC-downregulation, HCMV encodes proteins that enhance MHC-I expression to inhibit NK cells. For example, the peptides from UL40 have a high sequence similarity to peptides from HLA-C alleles (Tomasec et al. 2000; Ulbrecht et al. 2000). By binding to HLA-E, UL40 peptides can promote its expression on the cell surface, providing a ligand for NKG2A.

HIV-1 also decreases the expression of particular HLA alleles. HIV Nef binds to the cytoplasmic tails of the HLA$A$ and HLA-B molecules in the ER, re-directing them to endolysosomal compartments for degradation (Schaefer et al. 2008). Small differences in the cytoplasmic tails of HLA-C and HLA-E prevent Nef from hampering their transport to the cell surface, which in turn prevents HIV-infected cells to be lysed by most NK cells (Gall et al. 1998; Collins et al. 1998; Cohen et al. 1999).

Kaposi's sarcoma-associated herpesvirus (KSHV) is another example of viruses that can evade CTL responses via locus-specific MHC-I downregulation. KSVH encodes two membrane-bound ubiquitin E3 ligases, K3 and K5, which induce rapid internalization and degradation of MHC-I molecules (Coscoy and Ganem 2000; Ishido et al. 2000), yet with different specificities (Ishido et al. 2000). While K3 downregulates all four HLA allotypes (i.e., HLAA, HLA-B, HLA-C, and HLA-E), K5 impairs the expression of HLA-A and HLA-B, weakly downregulates HLA$\mathrm{C}$, but does not affect the expression of HLA-E (Ishido et al. 2000). Similarily, the EBV encoded protein BILF1 induces the rapid degradations of multiple HLA-A, -B, and -E molecules, but hardly affects the expression of HLAC (Griffin et al. 2013).

Table 3 Viral proteins inducing locus-specific MHC-I downregulation in humans

\begin{tabular}{lll}
\hline Virus protein & Downregulated HLA allotypes & Expressed HLA allotypes \\
\hline HCMV US2/US11 & HLA-A, HLA-B & HLA-C, HLA-E, HLA-G \\
HCMV UL40 & not applicable & HLA-E \\
HIV Nef & HLA-A, HLA-B & HLA-C \\
KSHV K5 & HLA-A, HLA-B, HLA-C (weakly) & HLA-E \\
EBV BILBF 1 & HLA-A, HLA-B, HLA-E & HLA-C \\
\hline
\end{tabular}


Mouse CMV (MCMV) encodes glycoproteins that interfere with the expression of MHC-I molecules (Wagner et al. 2002). For example, gp40 retains the MHC molecules in the ER (Ziegler et al. 1997), while gp48 re-routes mature MHC to endo-lysosomal compartments for degradation (Reusch et al. 1999). Balancing this broad MHC-I downregulation is the MCMV protein gp34, which escorts some MHC alleles to the cell surface (Kleijnen et al. 1997), and thereby allows infected cells to escape NK cell mediated killing.

All these examples highlight the evolutionary importance of viruses partially downregulating the expression of MHCI molecules. The specific targets for MHC downregulation (such as in HCMV or in HIV-1) illustrate the adaptation of the viruses to several MHC-I loci. By selectively downregulating MHC-I molecules, some viruses escape from NK cell responses. Thus, it is possible that the evolution of these various immunoevasins was driven by the selection pressures imposed by inhibiting NK cell receptors.

Our in silico studies of evolving host populations infected with herpes-like viruses that selectively downregulate one of the two MHC loci in the host (Carrillo-Bustamante et al. 2015b) showed that selective MHC downregulation exerts selection pressure to evolve specific NK cell receptors. Due to the infection with such viruses hosts naturally evolve inhibiting receptors that specialize to one MHC locus, while loosing their binding affinity to most MHC molecules in the other locus (Carrillo-Bustamante et al. 2015b). Importantly, the evolution of these "MHC locus" detectors exploits the similarity of the MHC alleles within each locus and depends on the difference between MHC loci. The easier it is to classify an MHC allele to its locus, the easier it is to evolve "locus specific" detectors, decreasing the selection pressure to diversify the genes encoding NK cell receptors. However, if MHC molecules in one locus resemble alleles from another locus, it becomes difficult for inhibiting receptors to discriminate between different MHC-I loci, driving the evolution of highly specific inhibiting receptors encoded in polygenic haplotypes.

These studies confirm the importance of MHC molecules on the evolution of NK cell receptors and are in line with the observation that inhibiting KIRs recognize motifs shared by common MHC epitopes, such as HLA-A3/A11, HLA-Bw4, HLA-C1, and HLA-C2 (Trowsdale et al. 2001). However, only the HLA-C ligands are locus specific, as the Bw4 epitope is also carried by $25 \%$ of HLA-A alleles (GonzalezGalarza et al. 2011), impeding the discrimination between HLA-A and HLA-B. Moreover, most HLA-A and HLA-B alleles (approximately two thirds in each locus) do not carry these KIR-specific epitopes (Gonzalez-Galarza et al. 2011), indicating that humans have not evolved optimal HLA-A or HLA-B detectors. Nevertheless, our results are in perfect agreement with the emergence of MHC-C specific detectors in chimpanzees and humans (i.e., lineage III KIRs). Why only MHC-C specific detectors have evolved remains puzzling and suggests that additional evasion mechanisms must have been involved in the evolution of MHC-A and MHC-B specific KIRs.

\section{MHC-I decoys in CMV}

In addition to selectively downregulating the expression of MHC I molecules, some viruses use MHC-I like proteins, i.e., decoys, that can directly interact with the NK cell receptors to modulate the immune response. Examples of such decoys are the HCMV encoded UL18 binding to the inhibitory LIR-1 (Prod'homme et al. 2007), and the MCMV encoded m144, mimicking key structural characteristics of H-2 molecules (Prod'homme et al. 2007; Natarajan et al. 2006). Interestingly, UL18 and m144 share more sequence similarity with MHC-I than they share with each other, showing that species-specific immune pressure led to independent acquisition of MHC-I mimics (Natarajan et al. 2006; Farrell et al. 1997).

The most extensively studied MHC decoy is the MCMV encoded m157 protein. m157 allows MCMV to avoid NK cell activation by engaging inhibitory receptors with high affinity, as shown in $129 / \mathrm{J}$ mice that are highly susceptible to MCMV infection (Smith et al. 2002). Unlike 129/J mice, C57BL/6 mice exhibit spontaneous resistance against MCMV, a phenomenon that has been genetically mapped to one single gene encoding the activating receptor Ly49H (Lee et al. 2001; Brown et al. 2001), which also binds $\mathrm{m} 157$ with high affinity (Lee et al. 2001; Smith et al. 2002). The activating Ly $49 \mathrm{H}$ evolved from its inhibitory counterpart Ly49I (Abi-Rached and Parham 2005), indicating that the evolution of the activating receptors is a result of the novel selective pressure exerted by CMV after evolving MHC-I decoys (Arase and Lanier 2002; Sun and Lanier 2009; Lanier 2008). The immuno-evasive role of m157 is further supported by studies of wild mouse-derived MCMV isolates where several strong interactions between $\mathrm{m} 157$ and an array of inhibitory receptors were detected. Only a few m157 variants engage the activating Ly49H receptor (Corbett et al. 2011; Voigt et al. 2003), indicating that the host's protection mediated by Ly49H is rather uncommon among wild mouse populations. Importantly, NK cell responses also exert strong immune pressure on the virus, as shown by experiments where the repeated passage of MCMV through resistant Ly49H mice resulted in the rapid evolution of m157 mutants that do not engage Ly49H, and thereby escape from the NK cell immune response (Voigt et al. 2003).

C57BL/6 is not the only inbred strain resistant to MCMV. Inbred MA/My mice also have low viral titers after infection with MCMV, although they do not possess the Ly49H 
gene. Their resistance is mediated by the activating receptor Ly49P which specifically recognizes MCMV infected cells in a H2- $\mathrm{D}^{\mathrm{k}}$ dependent manner (Kielczewska et al. 2009). Interestingly, this resistance requires the presence of the virally encoded protein m04, which escorts and binds newly assembled MHC-I molecules on the cell surface. Other activating receptors that recognize MCMV infection in a m04-H2 dependent manner include $\mathrm{Ly} 49 \mathrm{~L}^{\mathrm{BALB}}$, Ly49P1 ${ }^{\text {NOD }}$, and Ly49W1 ${ }^{\text {NOD }}$ (Pyzik et al. 2011). Like $\mathrm{m} 157$, the original function of $\mathrm{m} 04$ might have been to counteract the effect of MHC downregulation and avoid "missing-self" detection by inhibiting receptors. Together, these observations suggest that hosts evolved novel activating receptors to recognize the decoys evolved by viruses.

With a computational agent-based model of co-evolving hosts and CMV-like viruses (Carrillo-Bustamante et al. 2013, 2014, 2015c), we tested the effects of MHC-I decoys on the evolution of NK cell receptors. Our computational approach revealed that viruses evolving MHC-decoys drive the evolution of highly specific inhibiting receptors, i.e., receptors that specialize to particular MHC molecules in the population. Because inhibiting NK cell receptors face the challenge to avoid being "fooled" by the viral molecules mimicking MHC-I, such a high degree of specificity is optimal during infections with viruses evolving decoys. Similarly, activating receptors are beneficial in our in silico populations because of the protection they provide when they bind MHC-I decoys, thereby activating NK cells. Given their involvement in pathogen defense and host survival, we observe a natural expansion of the NK cell receptor cluster, evolving several haplotypes composed of specific inhibiting and activating genes.

Although these computational models provide insightful mechanistic insights into this evolutionary model, several questions remain still open. If activating NK cell receptors are indeed advantageous because they can recognize viral products, why is it so challenging to find and characterize ligands for them? It is possible that these viral ligands are encoded by short undetermined sequences in viruses having large genomes, such as CMV, EBV, and other viruses from the Herpes family. Another possible explanation for the lack of identified viral ligands is that viruses evolve rapidly, remaining a moving target for activating receptors, hence to impede their adaptation.

\section{Peptide sensitivity}

It is widely believed that, unlike $\mathrm{T}$ cell receptors, inhibiting KIRs (iKIRs) is not very specific for particular peptide-MHC (pMHC) complexes. However, several studies have shown that iKIRs can be sensitive to the specific peptides bound by the HLA molecules
(Malnati et al. 1995; Rajagopalan and Long 1997; Peruzzi et al. 1996; Thananchai et al. 2007; Hansasuta et al. 2004). Crystal structures of KIR2DL1 and KIR2DL2 in complex with their HLA-C ligands further supported this observation (Boyington et al. 2000; Brooks et al. 2000; Fan et al. 2001; Li and Mariuzza 2014), by revealing that specifically positions $7(\mathrm{P} 7)$ and $8(\mathrm{P} 8)$ of the bound peptide are in direct contact with residues of the iKIR. Other studies showed that peptides can markedly reduce or increase KIR-mediated inhibition (Cassidy et al. 2014; Fadda et al. 2010).

Because of the direct contact between iKIR and the MHC presented peptides, NK cell activation may vary in a peptide-dependent manner, making iKIRs sensitive to changes in the peptide repertoire presented by MHC-I molecules. These observations call for an extension of the current model of NK cell activation: "missing self" detection could be extended by "altered self", where changes in the MHC-I peptide repertoire modulate NK cell signaling.

The importance of peptide sensitivity has been recently emphasized by HIV-1 studies, demonstrating that sequence variations within HLA-C restricted HIV epitopes disrupt or promote the binding to inhibiting KIR2DL2, subsequently modifying NK cell activation (Fadda et al. 2012; van Teijlingen et al. 2014). Importantly, these studies show that a small number of naturally occurring variants of HIV-1 epitopes that are presented by HLA-C*03:04 can strongly engage KIR2DL2, inducing a strong inhibiting signal for the NK cells (van Teijlingen et al. 2014). It is tempting to speculate that viral variants are selected to avoid NK cell mediated immune responses in individuals expressing the corresponding KIR/HLA pair.

The changes in the MHC presented peptides after a viral infection are also expected to enhance the binding to activating receptors, allowing for NK cell activation. In mice, the interactions between the activating CD94/NKG2E and the peptides loaded onto the non-classical MHC-I Qa- ${ }^{b}$ have indeed been associated with enhanced viral control against mousepox infections (Fang et al. 2011). Qa- $1^{b}$ is normally loaded with small peptides derived from other self MHC-I molecules, which forms the natural ligand for the inhibiting CD94/NKG2A receptor. After mouse pox infection, these peptide-MHC complexes are no longer recognized by inhibiting receptors but they bind to activating receptors. The molecular mechanisms underlying this "altered-self" detection remain unknown, as it is not clear whether it is a viral or a newly expressed self peptide that is engaging the activating receptor. Nevertheless, this observation clearly highlights the importance of activating NK cell receptors in recognizing peptide-MHC complexes during viral infections, calling for further studies.

Our recent analysis of the peptides presented by HLA molecules before and after infection with measles virus (MV) has shed light on the required specificity for an 
inhibiting KIR to detect altered-self (Carrillo-Bustamante et al. 2015a). To be able to detect the changes in the peptide pool induced after a viral infection, inhibiting KIRs need to be sufficiently specific, i.e., they must be able to discriminate between any unique amino acid pairs or groups of amino acid groups in P7 and P8 (unpublished results). Because of this required specificity, an individual would need more than one inhibiting KIR to detect changes in the peptide repertoire after a viral infection, indicating that a diverse KIR repertoire is advantageous to successfully detect altered self. Further experimental elucidation of the KIR motifs in the MHC presented peptides is necessary to validate these predictions.

\section{Concluding remarks}

The evolution of NK cell receptors in different species led to a fascinating complexity. Most NK cell receptors interact with the highly polymorphic MHC molecules, resulting in receptor-ligand pairs that individualize the immune system, a process that is thought to improve hosts' survival. Yet, the exact evolutionary advantage of these expanded genotypes has remained unresolved. In this review, we have discussed several hypothesis that possibly underly the diversification of the NK cell receptor complex and provided some mechanistic insights into these viral-driven hypotheses, i.e., viral evolution of decoys, peptide sensitivity, and selective MHC-downregulation.

In the last 5 years, we have studied each of the hypotheses independently using computational and mathematical modeling. These studies revealed that each mechanism revised here can contribute, albeit in different degrees, to the evolution of polygenicity and polymorphism in the clusters encoding NK cell receptors. The studies reviewed here mirror the complexity of the biological process, as we now have several explanations for the complex biological question why NK cell receptors are specific, polygenic, and polymorphic. All these processes are most likely intertwined, simultaneously exerting pressures on hosts to evolve the functional NKR-MHC pairs which render NK cells protective. Therefore, the development of a more general model incorporating all three mechanisms (i.e., viral evolution of decoys, peptide sensitivity, and selective MHCdownregulation) is essential to quantify their contribution to the required genetic diversity for a population's longterm survival. A more complete model might shed also light onto how different pathogen interactions (i.e., several evasion mechanisms) influence the fixation of alternative NK receptor systems in different species. The evolutionary contribution of a diverse NK cell receptor repertoire to reproductive success remains still open and also calls for another extension of our models.

Importantly, the degree of genetic diversity that evolves in our simulations depends strongly on how the host's protection is modeled. In all our studies, the existence of MHC-I decoys (Carrillo-Bustamante et al. 2013, 2014, 2015 c) results in the evolution inhibiting receptors with a high degree of specificity recognizing very few MHC molecules in the population. This high specificity that hosts required to clear decoy-encoding viruses (which in turn exerts a stronger selection pressure on the NK cell receptors) depends on whether at least one or all inhibiting receptors in the licensed repertoire should be protective. Based on the experiments of MCMV infected 129/J mice which showed that one interaction between the inhibiting Ly49I and the decoy protein $\mathrm{m} 157$ is sufficient for the host to succumb the infection (Smith et al. 2002), we assumed that all inhibiting receptors must be protective to clear the infection. However, it is counterintuitive to have one inhibiting interaction dominating the host's NK cell response. Theoretically, if one inhibiting receptor is able to detect missing-self (i.e., to be protective), the NK cell subsets carrying that receptor should proliferate and provide some degree of protection. Indeed, relaxing this assumption (i.e., that a host needs at least one protective inhibiting receptors to clear the infection) results in a lower degree of diversity as shown by our model of selective downregulation (Carrillo-Bustamante et al. 2015b). The actual protection probably lies between all and at least one protective inhibiting NK cell receptors, but the current understanding of the contribution of each NK cell subset to host's protection during a viral infection remains limited.

Our computational models provided insightful mechanistic insights into viral selection pressures driving the evolution of NK cell receptors. For future extensions of these models, determining the complex, still unresolved, molecular and cellular processes of $\mathrm{NK}$ cells is crucial. Shedding light on these mechanisms, including the precise role of MHC-I molecules in NK cell maturation, the exact mechanisms of NKR repertoire acquisition, and the expansion of different NK cell subsets during viral infections, will allow us to better study the effects of NK cell education, and the diversity of NK cell subsets in fighting pathogens and survival.

Open Access This article is distributed under the terms of the Creative Commons Attribution 4.0 International License (http:// creativecommons.org/licenses/by/4.0/), which permits unrestricted use, distribution, and reproduction in any medium, provided you give appropriate credit to the original author(s) and the source, provide a link to the Creative Commons license, and indicate if changes were made. 


\section{References}

Abi-Rached L, Parham P (2005) Natural selection drives recurrent formation of activating killer cell immunoglobulin-like receptor and Ly49 from inhibitory homologues. J Exp Med 201(8):1319-1332. doi:10.1084/jem.20042558

Abi-Rached L, Moesta AK, Rajalingam R, Guethlein LA, Parham P (2010) Human-specific evolution and adaptation led to major qualitative differences in the variable receptors of human and chimpanzee natural killer cells. PLoS Genet 6(11):e1001,192. doi:10.1371/journal.pgen.1001192

Adams EJ, Parham P (2001) Species-specific evolution of MHC class I genes in the higher primates. Immunol Rev 183:41-64

Ahlenstiel G, Martin MP, Gao X, Carrington M, Rehermann B (2008) Distinct KIR/HLA compound genotypes affect the kinetics of human antiviral natural killer cell responses. J Clin Invest 118(3):1017-1026. doi:10.1172/JCI32400

Allan AJ, Sanderson ND, Gubbins S, Ellis SA, Hammond JA (2015) Cattle NK cell heterogeneity and the influence of MHC Class I. J Immunol:1500227

Alter G, Rihn S, Walter K, Nolting A, Martin M, Rosenberg ES, Miller JS, Carrington M, Altfeld M (2009) HLA class I subtypedependent expansion of KIR3DS1+ and KIR3DL1+ NK cells during acute human immunodeficiency virus type 1 infection. J Virol 83(13):6798-6805. doi:10.1128/JVI.00256-09

Amadei B, Urbani S, Cazaly A, Fisicaro P, Zerbini A, Ahmed P, Missale G, Ferrari C, Khakoo SI (2010) Activation of natural killer cells during acute infection with hepatitis $\mathrm{C}$ virus. Gastroenterology 138(4):1536-1545. doi:10.1053/j.gastro.2010.01.006

Arase H, Lanier LL (2002) Virus-driven evolution of natural killer cell receptors. Microbes Infect 4(15):1505-1512

Averdam A, Petersen B, Rosner C, Neff J, Roos C, Eberle M, Aujard F, Münch C, Schempp W, Carrington M, Shiina T, Inoko H, Knaust F, Coggill P, Sehra H, Beck S, Abi-Rached L, Reinhardt R, Walter L (2009) A novel system of polymorphic and diverse NK cell receptors in primates. PLoS Genet 5(10):e1000,688. doi:10.1371/journal.pgen.1000688

Barten R, Torkar M, Haude A, Trowsdale J, Wilson MJ (2001) Divergent and convergent evolution of NK-cell receptors. Trends Immunol 22(1):52-57

Bimber BN, Moreland AJ, Wiseman RW, Hughes AL, O'Connor DH (2008) Complete characterization of killer Ig-like receptor (KIR) haplotypes in Mauritian cynomolgus macaques: novel insights into nonhuman primate KIR gene content and organization. J Immunol 181(9):6301-6308

Blokhuis JH, van der Wiel MK, Doxiadis GGM, Bontrop RE (2010) The mosaic of KIR haplotypes in rhesus macaques. Immunogenetics 62(5):295-306. doi:10.1007/s00251-010-0434-3

Blokhuis JH, van der Wiel MK, Doxiadis GGM, Bontrop RE (2011) The extreme plasticity of killer cell Ig-like receptor (KIR) haplotypes differentiates rhesus macaques from humans. Eur J Immunol 41(9):2719-2728. doi:10.1002/eji.201141621

Borrego F, Ulbrecht M, Weiss EH, Coligan JE, Brooks AG (1998) Recognition of human histocompatibility leukocyte antigen (HLA)-E complexed with HLA class I signal sequence-derived peptides by CD94/NKG2 confers protection from natural killer cell-mediated lysis. J Exp Med 187 (5):813-818

Boyington JC, Motyka SA, Schuck P, Brooks AG, Sun PD (2000) Crystal structure of an NK cell immunoglobulin-like receptor in complex with its class I MHC ligand. Nature 405(6786):537-543. doi: $10.1038 / 35014520$
Braud VM, Söderström AKD, D’Andrea A, Ogg GS, Lazetic S, Young NT, Bell JI, Phillips JH, Lanier LL, McMichael AJ (1998) HLAE binds to natural killer cell receptors CD94/NKG2A, B and C. Nature 391(6669):795-799. doi:10.1038/35869

Brodin P, Kärre K, Höglund P (2009) NK cell education: not an onoff switch but a tunable rheostat. Trends Immunol 30(4):143-149. doi:10.1016/j.it.2009.01.006

Brooks AG, Boyington JC, Sun PD (2000) Natural killer cell recognition of HLA class I molecules. Rev Immunogenet 2(3):433-448

Brown MG, Dokun AO, Heusel JW, Smith HR, Beckman DL, Blattenberger EA, Dubbelde CE, Stone LR, Scalzo AA, Yokoyama WM (2001) Vital involvement of a natural killer cell activation receptor in resistance to viral infection. Science 292(5518):934-937

Carr WH, Rosen DB, Arase H, Nixon DF, Michaelsson J, Lanier LL (2007) Cutting Edge: KIR3 DS1, a gene implicated in resistance to progression to AIDS, encodes a DAP12-associated receptor expressed on NK cells that triggers NK cell activation. J Immunol 178(2):647-651

Carrillo-Bustamante $\mathrm{N}$ et al. (2015a) A license to kill. The evolution of NK cell receptors. Utrecht University

Carrillo-Bustamante P, Keşmir C, de Boer RJ (2013) Virus encoded MHC-like decoys diversify the inhibitory KIR repertoire. PLoS Comput Biol 9(10):e1003, 264. doi:10.1371/journal.pcbi.1003264

Carrillo-Bustamante P, Keşmir C, de Boer RJ (2014) Quantifying the protection of activating and inhibiting NK cell receptors during infection with a CMV-Like Virus. Front Immunol 5:20. doi:10.3389/fimmu.2014.00020

Carrillo-Bustamante P, Keşmir C, de Boer RJ (2015b) Can selective MHC downregulation explain the specificity and genetic diversity of NK cell receptors? Front Immunol 6(311). http://journal. frontiersin.org/article/10.3389/fimmu.2015.00311/full

Carrillo-Bustamante P, Keşmir C, de Boer RJ (2015c) A coevolutionary arms race between hosts and viruses drives polymorphism and polygenicity of NK cell receptors. Mol Bio Evo:msv096. doi:10.1093/molbev/msv096

Cassidy SA, Cheent KS, Khakoo SI (2014) Effects of Peptide on NK cell-mediated MHC I recognition. Front Immunol 5:133. doi:10.3389/fimmu.2014.00133

Cohen GB, Gandhi RT, Davis DM, Mandelboim O, Chen BK, Strominger JL, Baltimore D (1999) The selective downregulation of class I major histocompatibility complex proteins by HIV-1 protects HIV-infected cells from NK cells. Immunity 10(6):661671

Collins KL, Chen BK, Kalams SA, Walker BD, Baltimore D (1998) HIV-1 Nef protein protects infected primary cells against killing by cytotoxic T lymphocytes. Nature 391(6665):397-401. doi: $10.1038 / 34929$

Colonna M, Borsellino G, Falco M, Ferrara GB, Strominger JL (1993) HLA-C is the inhibitory ligand that determines dominant resistance to lysis by NK1- and NK2-specific natural killer cells. Proc Natl Acad Sci USA 90(24):12,000-12,004

Corbett AJ, Coudert JD, Forbes CA, Scalzo AA (2011) Functional consequences of natural sequence variation of murine cytomegalovirus m157 for Ly49 receptor specificity and NK cell activation. J Immunol 186(3):1713-1722. doi:10.4049/jimmunol.1003308

Coscoy L, Ganem D (2000) Kaposi's sarcoma-associated herpesvirus encodes two proteins that block cell surface display of MHC class I chains by enhancing their endocytosis. Proc Nat Acad Sci 97(14):8051-8056

Daza-Vamenta R, Glusman G, Rowen L, Guthrie B, Geraghty DE (2004) Genetic divergence of the rhesus macaque major 
histocompatibility complex. Genome Res 14(8):1501-1515. doi:10.1101/gr.2134504

Dobromylskyj M, Ellis S (2007) Complexity in cattle KIR genes: transcription and genome analysis. Immunogenetics 59(6):463-472. doi:10.1007/s00251-007-0215-9

Fadda L, Borhis G, Ahmed P, Cheent K, Pageon SV, Cazaly A, Stathopoulos S, Middleton D, Mulder A, Claas FHJ, Elliott T, Davis DM, Purbhoo MA, Khakoo SI (2010) Peptide antagonism as a mechanism for NK cell activation. Proc Natl Acad Sci USA 107(22):10,160-10,165. doi:10.1073/pnas.0913745107

Fadda L, Körner C, Kumar S, van Teijlingen NH, Piechocka-Trocha A, Carrington M, Altfeld M (2012) HLA-Cw*0102-restricted HIV1 p24 epitope variants can modulate the binding of the inhibitory KIR2DL2 receptor and primary NK cell function. PLoS Pathog 8(7):e1002,805. doi:10.1371/journal.ppat.1002805

Fan QR, Long EO, Wiley DC (2001) Crystal structure of the human natural killer cell inhibitory receptor KIR2DL1-HLA-Cw4 complex. Nat Immunol 2(5):452-460. doi:10.1038/87766

Fang M, Orr MT, Spee P, Egebjerg T, Lanier LL, Sigal LJ (2011) CD94 is essential for NK cell-mediated resistance to a lethal viral disease. Immunity 34(4):579-589. doi:10.1016/j.immuni.2011.02.015

Farrell HE, Vally H, Lynch DM, Fleming P, Shellam GR, Scalzo AA, Davis-Poynter NJ (1997) Inhibition of natural killer cells by a cytomegalovirus MHC class I homologue in vivo. Nature 386(6624):510-514. doi:10.1038/386510a0

Flornes LM, Nylenna $\varnothing$, Saether PC, Daws MR, Dissen E, Fossum S (2010) The complete inventory of receptors encoded by the rat natural killer cell gene complex. Immunogenetics 62(8):521-530. doi:10.1007/s00251-010-0455-y

Futas J, Horin P (2013) Natural killer cell receptor genes in the family Equidae: not only Ly49. PLoS One 8(5):e64,736. doi:10.1371/journal.pone.0064736

Gagnier L, Wilhelm BT, Mager DL (2003) Ly49 genes in non-rodent mammals. Immunogenetics 55(2):109-115. doi:10.1007/s00251-003-0558-9

Gall SL, Erdtmann L, Benichou S, Berlioz-Torrent C, Liu L, Benarous R, Heard JM, Schwartz O (1998) Nef interacts with the mu subunit of clathrin adaptor complexes and reveals a cryptic sorting signal in MHC I molecules. Immunity 8(4):483-495

Gendzekhadze K, Norman PJ, Abi-Rached L, Graef T, Moesta AK, Layrisse Z, Parham P (2009) Co-evolution of KIR2DL3 with HLA-C in a human population retaining minimal essential diversity of KIR and HLA class I ligands. Proc Natl Acad Sci USA 106(44):18,692-18,697. doi:10.1073/pnas.0906051106

Gewurz BE, Wang EW, Tortorella D, Schust DJ, Ploegh HL (2001) Human cytomegalovirus US2 endoplasmic reticulum-lumenal domain dictates association with major histocompatibility complex class I in a locus-specific manner. J Virol 75(11):5197-5204. doi:10.1128/JVI.75.11.5197-5204.2001

Gillespie GMA, Bashirova A, Dong T, McVicar DW, Rowland-Jones SL, Carrington M (2007) Lack of KIR3DS1 binding to MHC class I Bw4 tetramers in complex with CD8+ T cell epitopes. AIDS Res Hum Retroviruses 23(3):451-455. doi:10.1089/aid.2006.0165

Gonzalez-Galarza FF, Christmas S, Middleton D, Jones AR (2011) Allele frequency net: a database and online repository for immune gene frequencies in worldwide populations. Nucleic acids research 39(suppl 1):D913-D919

Griffin BD, Gram AM, Mulder A, Van Leeuwen D, Claas FH, Wang F, Ressing ME, Wiertz E (2013) EBV BILF1 evolved to downregulate cell surface display of a wide range of HLA class I molecules through their cytoplasmic tail. J Immunol 190(4):1672-1684

Guethlein LA, Flodin LR, Adams EJ, Parham P (2002) NK cell receptors of the orangutan (Pongo pygmaeus): a pivotal species for tracking the coevolution of killer cell Ig-like receptors with MHC-C. J Immunol 169(1):220-229

Guethlein LA, Abi-Rached L, Hammond JA, Parham P (2007a) The expanded cattle KIR genes are orthologous to the conserved single-copy KIR3DX1 gene of primates. Immunogenetics 59(6):517-522. doi:10.1007/s00251-007-0214-x

Guethlein LA, Older Aguilar AM, Abi-Rached L, Parham P (2007b) Evolution of killer cell Ig-like receptor (KIR) genes: definition of an orangutan KIR haplotype reveals expansion of lineage III KIR associated with the emergence of MHC-C. J Immunol 179(1):491504

Gumperz JE, Litwin V, Phillips JH, Lanier LL, Parham P (1995) The Bw4 public epitope of HLA-B molecules confers reactivity with natural killer cell clones that express NKB1, a putative HLA receptor. J Exp Med 181(3):1133-1144

Gumperz JE, Barber LD, Valiante NM, Percival L, Phillips JH, Lanier LL, Parham P (1997) Conserved and variable residues within the Bw4 motif of HLA-B make separable contributions to recognition by the NKB1 killer cell-inhibitory receptor. J Immunol 158(11):5237-5241

Hammond JA, Guethlein LA, Abi-Rached L, Moesta AK, Parham $P$ (2009) Evolution and survival of marine carnivores did not require a diversity of killer cell Ig-like receptors or Ly49 NK cell receptors. J Immunol 182(6):3618-3627. doi:10.4049/jimmunol.0803026

Hansasuta P, Dong T, Thananchai H, Weekes M, Willberg C, Aldemir H, Rowland-Jones S, Braud VM (2004) Recognition of HLA-A3 and HLA-A11 by KIR3DL2 is peptide-specific. Eur J Immunol 34(6):1673-1679. doi:10.1002/eji.200425089

Hershberger KL, Shyam R, Miura A, Letvin NL (2001) Diversity of the killer cell Ig-like receptors of rhesus monkeys. J Immunoly 166(7):4380-4390. doi:10.4049/jimmunol.166.7.4380

Hiby SE, Walker JJ, O'shaughnessy KM, Redman CWG, Carrington M, Trowsdale J, Moffett A (2004) Combinations of maternal KIR and fetal HLA-C genes influence the risk of preeclampsia and reproductive success. J Exp Med 200(8):957-965. doi:10.1084/jem.20041214

Hiby SE, Apps R, Sharkey AM, Farrell LE, Gardner L, Mulder A, Claas FH, Walker JJ, Redman CW, Redman CC, Morgan L, Tower C, Regan L, Moore GE, Carrington M, Moffett A (2010) Maternal activating KIRs protect against human reproductive failure mediated by fetal HLA-C2. J Clin Invest 120(11):4102-4110. doi:10.1172/JCI43998

Hiby SE, Apps R, Chazara O, Farrell LE, Magnus P, Trogstad L, Gjessing HK, Carrington M, Moffett A (2014) Maternal KIR in combination with paternal HLA-C2 regulate human birth weight. J Immunol 192(11):5069-5073. doi:10.4049/jimmunol.1400577

Höglund P, Brodin P (2010) Current perspectives of natural killer cell education by MHC class I molecules. Nat Rev Immunol 10(10):724-734. doi:10.1038/nri2835

Hollenbach JA, Meenagh A, Sleator C, Alaez C, Bengoche M, Canossi A, Contreras G, Creary L, Evseeva I, Gorodezky C, Hardie RA, Karlsen TH, Lie B, Luo M, Martinetti M, Navarette C, de Oliveira DCM, Ozzella G, Pasi A, Pavlova E, Pinto S, Porto LC, Santos P, Slavcev A, Srinak D, Tavoularis S, Tonks S, Trachtenberg E, Vejbaesya S, Middleton D (2010) Report from the killer immunoglobulin-like receptor (KIR) anthropology component of the 15th International Histocompatibility Workshop: worldwide variation in the KIR loci and further evidence for the co-evolution of KIR and HLA. Tissue Antigens 76(1):9-17. doi:10.1111/j.1399-0039.2010.01459.x

Horowitz A, Strauss-Albee DM, Leipold M, Kubo J, Nemat-Gorgani N, Dogan OC, Dekker CL, Mackey S, Maecker H, Swan GE, Davis MM, Norman PJ, Guethlein LA, Desai M, Parham P, Blish CA (2013) Genetic and environmental determinants of human 
NK cell diversity revealed by mass cytometry. Sci Transl Med 5(208):208ra145. doi:10.1126/scitranslmed.3006702

Husain Z, Alper CA, Yunis EJ, Dubey DP (2002) Complex expression of natural killer receptor genes in single natural killer cells. Immunology 106(3):373-380

Iizuka K, Naidenko OV, Plougastel BFM, Fremont DH, Yokoyama WM (2003) Genetically linked C-type lectin-related ligands for the NKRP1 family of natural killer cell receptors. Nat Immunol 4(8):801-807. doi:10.1038/ni954

Ishido S, Wang C, Lee BS, Cohen GB, Jung J (2000) Downregulation of major histocompatibility complex class i molecules by Kaposi's sarcoma-associated herpesvirus K3 and K5 proteins. J Virol 74(11):5300-5309

Jamil KM, Khakoo SI (2011) (2011) KIR/HLA interactions and pathogen immunity. J Biomed Biotechnol 298:348. doi: $10.1155 / 2011 / 298348$

Kelley J, Walter L, Trowsdale J (2005) Comparative genomics of natural killer cell receptor gene clusters. PLoS Genet 1(2):129-139. doi:10.1371/journal.pgen.0010027

Khakoo SI, Rajalingam R, Shum BP, Weidenbach K, Flodin L, Muir DG, Canavez F, Cooper SL, Valiante NM, Lanier LL, Parham P (2000) Rapid evolution of NK cell receptor systems demonstrated by comparison of chimpanzees and humans. Immunity 12(6):687698

Khakoo SI, Thio CL, Martin MP, Brooks CR, Gao X, Astemborski J, Cheng J, Goedert JJ, Vlahov D, Hilgartner M, Cox S, Little AM, Alexander GJ, Cramp ME, O’Brien SJ, Rosenberg WMC, Thomas DL, Carrington M (2004) HLA and NK cell inhibitory receptor genes in resolving hepatitis $\mathrm{C}$ virus infection. Science 305(5685):872-874. doi:10.1126/science. 1097670

Kieckbusch J, Gaynor LM, Moffett A, Colucci F (2014) MHCdependent inhibition of uterine NK cells impedes fetal growth and decidual vascular remodelling. Nat Commun 5:3359. doi:10.1038/ncomms4359

Kielczewska A, Pyzik M, Sun T, Krmpotic A, Lodoen MB, Munks MW, Babic M, Hill AB, Koszinowski UH, Jonjic S, Lanier LL, Vidal SM (2009) Ly49P recognition of cytomegalovirus-infected cells expressing $\mathrm{H} 2-\mathrm{Dk}$ and $\mathrm{CMV}$-encoded $\mathrm{m} 04$ correlates with the NK cell antiviral response. J Exp Med 206(3):515-523. doi:10.1084/jem.20080954

Kikuchi-Maki A, Catina TL, Campbell KS (2005) Cutting edge: KIR2DL4 transduces signals into human NK cells through association with the $\mathrm{Fc}$ receptor gamma protein. J Immunol 174(7):3859-3863

Kirkham CL, Carlyle JR (2014) Complexity and Diversity of the NKRP1:Clr (Klrb1:Clec2) recognition Systems. Front Immunol 5:214. doi:10.3389/fimmu.2014.00214

Kleijnen MF, Huppa JB, Lucin P, Mukherjee S, Farrell H, Campbell AE, Koszinowski UH, Hill AB, Ploegh HL (1997) A mouse cytomegalovirus glycoprotein, gp34, forms a complex with folded class I MHC molecules in the ER which is not retained but is transported to the cell surface. EMBO J 16(4):685-694. doi:10.1093/emboj/16.4.685

Kruse PH, Rosner C, Walter L (2010) Characterization of rhesus macaque KIR genotypes and haplotypes. Immunogenetics 62(5):281-293. doi:10.1007/s00251-010-0433-4

Kubagawa H, Cooper M, Chen C, Ho L, Alley T, Hurez V, Tun T, Uehara T, Shimada T, Burrows P (1999) Paired immunoglobulinlike receptors of activating and inhibitory types. In: Immunoreceptor Tyrosine-based Inhibition Motifs, Springer, pp 137149

La D, Czarnecki C, El-Gabalawy H, Kumar A, Meyers AFA, Bastien N, Simonsen JN, Plummer FA, Luo M (2011) Enrichment of variations in KIR3DL1/S1 and KIR2DL2/L3 among H1N1/09
ICU patients: an exploratory study. PLoS One 6(12):e29,200. doi:10.1371/journal.pone.0029200

LaBonte ML, Hershberger KL, Korber B, Letvin NL (2001) The KIR and CD94/NKG2 families of molecules in the rhesus monkey. Immunol Rev 183:25-40

Lanier LL (2005) NK cell recognition. Annu Rev Immunol 23:225274. doi:10.1146/annurev.immunol.23.021704.115526

Lanier LL (2008) Evolutionary struggles between NK cells and viruses. Nat Rev Immunol 8(4):259-268. doi:10.1038/nri2276

Lazetic S, Chang C, Houchins JP, Lanier LL, Phillips JH (1996) Human natural killer cell receptors involved in MHC class I recognition are disulfide-linked heterodimers of CD94 and NKG2 subunits. J Immunol 157(11):4741-4745

Lee SH, Girard S, Macina D, Busà M, Zafer A, Belouchi A, Gros P, Vidal SM (2001) Susceptibility to mouse cytomegalovirus is associated with deletion of an activating natural killer cell receptor of the C-type lectin superfamily. Nat Genet 28(1):42-45. doi: $10.1038 / 88247$

Leonard WR, Snodgrass JJ, Robertson ML (2007) Effects of brain evolution on human nutrition and metabolism. Annu Rev Nutr 27:311-327. doi:10.1146/annurev.nutr.27.061406.093659

Li Y, Mariuzza RA (2014) Structural basis for recognition of cellular and viral ligands by NK cell receptors. Front Immunol 5:123. doi:10.3389/fimmu.2014.00123

Ljunggren HG, Kärre K (1990) In search of the 'missing self': MHC molecules and NK cell recognition. Immunol Today 11(7):237244

Llano M, Gumá M, Ortega M, Angulo A, López-Botet M (2003) Differential effects of US2, US6 and US11 human cytomegalovirus proteins on HLA class Ia and HLA-E expression: impact on target susceptibility to NK cell subsets. Eur J Immunol 33(10):27442754. doi:10.1002/eji.200324182

López-Vázquez A, Rodrigo L, Martínez-Borra J, Pérez R, Rodríguez M, Fdez-Morera JL, Fuentes D, Rodríguez-Rodero S, Gonzáez S, López-Larrea C (2005) Protective effect of the HLA-Bw4I80 epitope and the killer cell immunoglobulin-like receptor 3DS1 gene against the development of hepatocellular carcinoma in patients with hepatitis C virus infection. J Infect Dis 192(1):162-165. doi:10.1086/430351

Malnati MS, Peruzzi M, Parker KC, Biddison WE, Ciccone E, Moretta A, Long EO (1995) Peptide specificity in the recognition of MHC class I by natural killer cell clones. Science 267(5200):10161018

Martin AM, Freitas EM, Witt CS, Christiansen FT (2000) The genomic organization and evolution of the natural killer immunoglobulinlike receptor (KIR) gene cluster. Immunogenetics 51(4-5):268280

Martin AM, Pontarotti JK, Christiansen FT (2002a) Leukocyte Iglike receptor complex (LRC) in mice and men. Trends Immunol 23(2):81-88

Martin MP, Gao X, Lee JH, Nelson GW, Detels R, Goedert JJ, Buchbinder S, Hoots K, Vlahov D, Trowsdale J, Wilson M, O'Brien SJ, Carrington M (2002b) Epistatic interaction between KIR3DS1 and HLA-B delays the progression to AIDS. Nat Genet 31(4):429-434. doi:10.1038/ng934

Martin MP, Bashirova A, Traherne J, Trowsdale J, Carrington M (2003) Cutting edge: expansion of the KIR locus by unequal crossing over. J Immunol 171(5):21922195

McQueen KL, Freeman JD, Takei F, Mager DL (1998) Localization of five new Ly49 genes, including three closely related to Ly49c. Immunogenetics 48(3):174-183

Moesta AK, Graef T, Abi-Rached L, Older Aguilar AM, Guethlein LA, Parham P (2010) Humans differ from other hominids in 
lacking an activating NK cell receptor that recognizes the C1 epitope of MHC class I. J Immunol 185(7):4233-4237. doi:10.4049/jimmunol.1001951

Moffett A, Loke C (2006) Immunology of placentation in eutherian mammals. Nat Rev Immunol 6(8):584-594. doi:10.1038/ nri1897

Moffett-King A (2002) Natural killer cells and pregnancy. Nat Rev Immunol 2(9):656-663. doi:10.1038/nri886

Moretta A, Tambussi G, Bottino C, Tripodi G, Merli A, Ciccone E, Pantaleo G, Moretta L (1990) A novel surface antigen expressed by a subset of human CD3- CD16+ natural killer cells. Role in cell activation and regulation of cytolytic function. J Exp Med 171(3):695-714

Nash WT, Teoh J, Wei H, Gamache A, Brown MG (2014) Know thyself: NK-cell inhibitory receptors prompt selftolerance, education, and viral control. Front Immunol 5:175. doi:10.3389/fimmu.2014.00175

Natarajan K, Hicks A, Mans J, Robinson H, Guan R, Mariuzza RA, Margulies DH (2006) Crystal structure of the murine cytomegalovirus MHC-I homolog m144. J Mol Biol 358(1):157171. doi:10.1016/j.jmb.2006.01.068

Nemat-Gorgani N, Edinur HA, Hollenbach JA, Traherne JA, Dunn PPJ, Chambers GK, Parham P, Norman PJ (2014) KIR diversity in Māori and Polynesians: populations in which HLA-B is not a significant KIR ligand. Immunogenetics 66(11):597-611. doi:10.1007/s00251-014-0794-1

Norman PJ, Hollenbach JA, Nemat-Gorgani N, Guethlein LA, Hilton HG, Pando MJ, Koram KA, Riley EM, Abi-Rached L, Parham P (2013) Co-evolution of human leukocyte antigen (HLA) class I ligands with killer-cell immunoglobulin-like receptors (KIR) in a genetically diverse population of sub-Saharan Africans. PLoS Genet 9(10):e1003,938. doi:10.1371/journal.pgen.1003938

Nylenna O, Naper C, Vaage JT, Woon PY, Gauguier D, Dissen E, Ryan JC, Fossum S (2005) The genes and gene organization of the Ly49 region of the rat natural killer cell gene complex. Eur J Immunol 35(1):261-272. doi:10.1002/eji.200425429

O'Connor GM, Guinan KJ, Cunningham RT, Middleton D, Parham P, Gardiner CM (2007) Functional polymorphism of the KIR3DL1/S1 receptor on human NK cells. J Immunol 178(1):235-241

O'Connor GM, Vivian JP, Gostick E, Pymm P, Lafont BA, Price DA, Rossjohn J, Brooks AG, McVicar DW (2015) Peptide-dependent recognition of HLA-B* 57: 01 by KIR3DS1. J Virol 89(10):52135221

Parham P (2005) Influence of KIR diversity on human immunity. Adv Exp Med Biol 560:47-50. doi:10.1007/0-387-24180-9_6

Parham P, Moffett A (2013) Variable NK cell receptors and their MHC class I ligands in immunity, reproduction and human evolution. Nat Rev Immunol 13(2):133-144. doi:10.1038/nri3370

Pelak K, Need AC, Fellay J, Shianna KV, Feng S, Urban TJ, Ge D, De Luca A, Martinez-Picado J, Wolinsky SM, Martinson JJ, Jamieson BD, Bream JH, Martin MP, Borrow P, Letvin NL, McMichael AJ, Haynes BF, Telenti A, Carrington M, Goldstein DB, Alter G (2011) Copy number variation of KIR genes influences HIV-1 control. PLoS Biol 9(11):e1001,208. doi:10.1371/journal.pbio.1001208

Peruzzi M, Wagtmann N, Long EO (1996) A p70 killer cell inhibitory receptor specific for several HLA-B allotypes discriminates among peptides bound to HLA-B*2705. J Exp Med 184(4): $1585-1590$

Petrie EJ, Clements CS, Lin J, Sullivan LC, Johnson D, Huyton T, Heroux A, Hoare HL, Beddoe T, Reid HH, Wilce MCJ, Brooks AG, Rossjohn J (2008) CD94-NKG2A recognition of human leukocyte antigen (HLA)-E bound to an HLA class I leader sequence. J Exp Med 205(3):725-735. doi:10.1084/jem.20072525

Prod'homme V, Griffin C, Aicheler RJ, Wang ECY, McSharry BP, Rickards CR, Stanton RJ, López-Botet WGWG, Tomasec P (2007) The human cytomegalovirus MHC class I homolog UL18 inhibits LIR-1+ but activates LIR-1- NK cells. J Immunol 178(7):4473-4481

Pyo CW, Guethlein LA, Vu Q, Wang R, Abi-Rached L, Norman PJ, Marsh SGE, Miller JS, Parham P, Geraghty DE (2010) Different patterns of evolution in the centromeric and telomeric regions of group A and B haplotypes of the human killer cell Ig-like receptor locus. PLoS One 5(12) e15:115. doi:10.1371/journal.pone.0015115

Pyzik M, Charbonneau B, Gendron-Pontbriand EM, Babić M, Krmpotić A, Jonjić S, Vidal SM (2011) Distinct MHC class Idependent NK cell-activating receptors control cytomegalovirus infection in different mouse strains. J Exp Med 208(5):1105-1117. doi:10.1084/jem.20101831

Rahim MMA, Tu MM, Mahmoud AB, Wight A, Abou-Samra E, Lima PDA, Makrigiannis AP (2014) Ly49 receptors: innate and adaptive immune paradigms. Front Immunol 5:145. doi:10.3389/fimmu.2014.00145

Rajagopalan S (2010) Endosomal signaling and a novel pathway defined by the natural killer receptor KIR2DL4 (CD158d). Traffic 11(11):1381-1390. doi:10.1111/j.1600-0854.2010.01112.x

Rajagopalan S, Long EO (1997) The direct binding of a p58 killer cell inhibitory receptor to human histocompatibility leukocyte antigen (HLA)-Cw4 exhibits peptide selectivity. J Exp Med 185(8):15231528

Raulet DH, Vance RE (2006) Self-tolerance of natural killer cells. Nat Rev Immunol 6(7):520-531. doi: $10.1038 /$ nri1863

Raulet DH, Held W, Correa I, Dorfman JR, Wu MF, Corral L (1997) Specificity, tolerance and developmental regulation of natural killer cells defined by expression of class I-specific Ly49 receptors. Immunol Rev 155:41-52

Renedo M, Arce I, Rodríguez A, Carretero M, López-Botet LL, Fernández-Ruiz E (1997) The human natural killer gene complex is located on chromosome 12p12-p13. Immunogenetics 46(4):307-311

Reusch U, Muranyi W, Lucin P, Burgert HG, Hengel H, Koszinowski UH (1999) A cytomegalovirus glycoprotein re-routes MHC class I complexes to lysosomes for degradation. EMBO J 18(4):10811091. doi:10.1093/emboj/18.4.1081

Robson SL, Wood B (2008) Hominin life history: reconstruction and evolution. $\mathrm{J}$ Anat 212(4):394-425. doi:10.1111/j.1469-7580.2008.00867.x

Romero V, Azocar J, niga JZ, Clavijo OP, Terreros D, Gu X, Husain Z, Chung RT, Amos C, Yunis EJ (2008) Interaction of NK inhibitory receptor genes with HLA-C and MHC class II alleles in Hepatitis C virus infection outcome. Mol Immunol 45(9):2429-2436. doi:10.1016/j.molimm.2008.01.002

Sanjanwala B, Draghi M, Norman PJ, Guethlein LA, Parham P (2008) Polymorphic sites away from the Bw4 epitope that affect interaction of Bw4+ HLA-B with KIR3DL1. J Immunol 181(9):62936300

Saunders PM, Vivian JP, Baschuk N, Beddoe T, Widjaja J, O’Connor GM, Hitchen C, Pymm P, Andrews DM, Gras S, McVicar DW, Rossjohn J, Brooks AG (2015) The interaction of KIR3DL1*001 with HLA Class I molecules is dependent upon molecular microarchitecture within the Bw4 Epitope. J Immunol 194(2):781-789. doi:10.4049/jimmunol.1402542 
Schaefer MR, Wonderlich ER, Roeth JF, Leonard JA, Collins KL (2008) HIV-1 Nef targets MHC-I and CD4 for degradation via a final common beta-COP-dependent pathway in T cells. PLoS Pathog 4(8) e1000:131. doi:10.1371/journal.ppat.1000131

Schafer JL, Colantonio AD, Neidermyer WJ, Dudley DM, Connole M, O'Connor DH, Evans DT (2014) KIR3DL01 recognition of Bw4 ligands in the rhesus macaque: maintenance of Bw4 specificity since the divergence of apes and Old World monkeys. J Immunol 192(4):1907-1917. doi:10.4049/jimmunol.1302883

Schenkel AR, Kingry LC, Slayden RA (2013) The ly49 gene family. A brief guide to the nomenclature, genetics, and role in intracellular infection. Front Immunol 4:90. doi:10.3389/fimmu.2013.00090

Schust DJ, Tortorella D, Seebach J, Phan C, Ploegh HL (1998) Trophoblast class I major histocompatibility complex (MHC) products are resistant to rapid degradation imposed by the human cytomegalovirus (HCMV) gene products US2 and US11. J Exp Med 188(3):497-503

Sharkey AM, Gardner L, Hiby S, Farrell L, Apps R, Masters L, Goodridge J, Lathbury L, Stewart CA, Verma S, Moffett A (2008) Killer Ig-like receptor expression in uterine NK cells is biased toward recognition of HLA-C and alters with gestational age. J Immunol 181(1):39-46

Shiina T, Ota M, Shimizu S, Katsuyama Y, Hashimoto N, Takasu M, Anzai T, Kulski JK, Kikkawa E, Naruse T, Kimura N, Yanagiya K, Watanabe A, Hosomichi K, Kohara S, Iwamoto C, Umehara Y, Meyer A, Wanner V, Sano K, Macquin C, Ikeo K, Tokunaga K, Gojobori T, Inoko H, Bahram S (2006) Rapid evolution of major histocompatibility complex class I genes in primates generates new disease alleles in humans via hitchhiking diversity. Genetics 173(3):1555-1570. doi:10.1534/genetics.106.057034

Shum BP, Flodin LR, Muir DG, Rajalingam R, Khakoo SI, Cleland S, Guethlein LA, Uhrberg M, Parham P (2002) Conservation and variation in human and common chimpanzee CD94 and NKG2 genes. J Immunol 168(1):240-252

Smith HRC, Heusel JW, Mehta IK, Körner BG, Naidenko OV, Iizuka K, Furukawa H, Beckman DL, Pingel JT, Scalzo AA, Fremont DH, Yokoyama WM (2002) Recognition of a virus-encoded ligand by a natural killer cell activation receptor. Proc Natl Acad Sci USA 99(13):8826-8831. doi:10.1073/pnas.092258599

Sun JC, Lanier LL (2009) The natural selection of herpesviruses and virus-Specific NK Cell Receptors. Viruses 1(3):362. doi:10.3390/v1030362

Takahashi T, Yawata M, Raudsepp T, Lear TL, Chowdhary BP, Antczak DF, Kasahara M (2004) Natural killer cell receptors in the horse: evidence for the existence of multiple transcribed LY49 genes. Eur J Immunol 34(3):773-784. doi:10.1002/eji.200324695

van Teijlingen NH, Hölzemer A, Körner C, García-Beltrán WF, Schafer JL, Fadda L, Suscovich TJ, Brander C, Carrington M, Evans DT, van Baarle D, Altfeld M (2014) Sequence variations in HIV-1 p24 Gag-derived epitopes can alter binding of KIR2DL2 to HLA-C*03: 04 and modulate primary natural killer cell function. AIDS 28(10):1399-1408. doi:10.1097/QAD.0000000000000284

Thananchai H, Gillespie G, Martin MP, Bashirova A, Yawata N, Yawata M, Easterbrook P, McVicar DW, Maenaka K, Parham P, Carrington M, Dong T, Rowland-Jones S (2007) Cutting Edge: Allele-specific and peptide-dependent interactions between KIR3DL1 and HLA-A and HLA-B. J Immunol 178(1):33-37

Tomasec P, Braud VM, Rickards C, Powell MB, McSharry BP, Gadola $\mathrm{S}$, Cerundolo V, Borysiewicz LK, McMichael AJ, Wilkinson GW (2000) Surface expression of HLA-E, an inhibitor of natural killer cells, enhanced by human cytomegalovirus gpUL40. Science 287(5455):1031
Trowsdale J (2001) Genetic and functional relationships between MHC and NK receptor genes. Immunity 15(3):363-374

Trowsdale J, Barten R, Haude A, Stewart CA, Beck S, Wilson MJ (2001) The genomic context of natural killer receptor extended gene families. Immunol Rev 181:20-38

Ulbrecht M, Martinozzi S, Grzeschik M, Hengel H, Ellwart JW, Pla M, Weiss EH (2000) Cutting edge: the human cytomegalovirus UL40 gene product contains a ligand for HLAE and prevents NK cell-mediated lysis. J Immunol 164(10):50195022

Valiante NM, Uhrberg M, Shilling HG, Lienert-Weidenbach K, Arnett KL, D'Andrea A, Phillips JH, Lanier LL, Parham P (1997) Functionally and structurally distinct NK cell receptor repertoires in the peripheral blood of two human donors. Immunity 7(6):739-751

Vilches C, Parham P (2002) KIR: diverse, rapidly evolving receptors of innate and adaptive immunity. Annu Rev Immunol 20:217-251. doi:10.1146/annurev.immunol.20.092501.134942

Vivian JP, Duncan RC, Berry R, O'Connor GM, Reid HH, Beddoe T, Gras S, Saunders PM, Olshina MA, Widjaja JML, Harpur CM, Lin J, Maloveste SM, Price DA, Lafont BAP, McVicar DW, Clements CS, Brooks AG, Rossjohn J (2011) Killer cell immunoglobulinlike receptor 3DL1-mediated recognition of human leukocyte antigen B. Nature 479(7373):401-405. doi:10.1038/nature10517

Vivier E, Nunès JA, Vély F (2004) Natural killer cell signaling pathways. Science 306(5701):1517-1519. doi:10.1126/science. 1103478

Vivier E, Tomasello E, Baratin M, Walzer T, Ugolini S (2008) Functions of natural killer cells. Nat Immunol 9(5):503-510. doi:10.1038/ni1582

Voigt V, Forbes CA, Tonkin JN, Degli-Esposti MA, Smith HRC, Yokoyama WM, Scalzo AA (2003) Murine cytomegalovirus m157 mutation and variation leads to immune evasion of natural killer cells. Proc Natl Acad Sci USA 100(23):13,483-13,488. doi:10.1073/pnas.2233572100

Wagner M, Gutermann A, Podlech J, Reddehase MJ, Koszinowski UH (2002) Major histocompatibility complex class I allelespecific cooperative and competitive interactions between immune evasion proteins of cytomegalovirus. J Exp Med 196 (6):805-816

Wallace AE, Fraser R, Cartwright JE (2012) Extravillous trophoblast and decidual natural killer cells: a remodelling partnership. Hum Reprod Update 18(4):458-471. doi:10.1093/humupd/dms015

Walter L (2011) Major histocompatibility complex class-I-interacting natural killer cell receptors of nonhuman primates. J Innate Immun 3(3):236-241

Wende H, Colonna M, Ziegler A, Volz A (1999) Organization of the leukocyte receptor cluster (LRC) on human chromosome 19q13.4. Mamm Genome 10(2):154-160

Wilhelm BT, Gagnier L, Mager DL (2002) Sequence analysis of the ly49 cluster in C57BL/6 mice: a rapidly evolving multigene family in the immune system. Genomics 80(6):646-661

Wilson MJ, Torkar M, Haude A, Milne S, Jones T, Sheer D, Beck S, Trowsdale J (2000) Plasticity in the organization and sequences of human KIR/ILT gene families. Proc Nat Acad Sci 97(9):47784783

Winter CC, Gumperz JE, Parham P, Long EO, Wagtmann N (1998) Direct binding and functional transfer of nk cell inhibitory receptors reveal novel patterns of HLA-C allotype recognition. J Immunoly (Baltimore Md: 1950) 161(2):571-577

Xiong S, Sharkey AM, Kennedy PR, Gardner L, Farrell LE, Chazara O, Bauer J, Hiby SE, Colucci F, Moffett A (2013) Maternal uterine NK cell-activating receptor KIR2DS1 enhances placentation. J Clin Invest 123(10):4264-4272. doi:10.1172/JCI68991 
Yawata M, Yawata N, Draghi M, Little AM, Partheniou F, Parham P (2006) Roles for HLA and KIR polymorphisms in natural killer cell repertoire selection and modulation of effector function. J Exp Med 203(3):633-645. doi:10.1084/jem.20051884

Zeng L, Sullivan LC, Vivian JP, Walpole NG, Harpur CM, Rossjohn J, Clements CS, Brooks AG (2012) A structural basis for antigen presentation by the MHC class Ib molecule, Qa-1b. J Immunol 188(1):302-310. doi:10.4049/jimmunol.1102379

Ziegler H, Thale R, Lucin P, Muranyi W, Flohr T, Hengel H, Farrell H, Rawlinson W, Koszinowski UH (1997) A mouse cytomegalovirus glycoprotein retains MHC class I complexes in the ERGIC/cisGolgi compartments. Immunity 6(1):57-66 